\title{
THE INFLUENCE OF THE SOIL ENVIRONMENT ON THE CORROSIVITY OF FAILURE INFRASTRUCTURE - CASE STUDY OF THE EXEMPLARY WATER NETWORK
}

\section{A. PEKALA ${ }^{1}$ K.PIETRUCHA -URBANIK ${ }^{2}$}

In the paper the issue connected with water network failure regarding the soil conditions was presented. Water pipes constitute a large part of water company asset. Therefore the analysis concerning the influence of soil conditions into failure occurrence of water pipe is crucial for proper functioning of water supply systems (WSS). In the performed studies the real data from the operation of the exemplary WSS was obtained. The following properties of the ground conditions were taken into consideration among others: the chemical composition and ground phase, based on analysis performed through the following equipment, as the electron microscope with X-ray spectrometer detector and backscattered electrons (BSE) using the powder Debye-Sherrer's method and X-ray diffractometer. The analysis indicate dependence between soil conditions and corrosivity occurrence, what indicate the importance of performed analysis.

Keywords: soil parameters and properties, water supply system, conditions for corrosivity occurrence

\section{INTRODUCTION}

External working conditions of materials building water supply network are largely influenced by the environmental factors that can frequently cause a lot of destruction and damage. Pipes are subjected to corrosion, transverse and longitudinal cracks and also mechanical damage. One

\footnotetext{
${ }^{1}$ PhD., Eng., Rzeszow University of Technology, Faculty of Civil, Environmental Engineering and Architecture, ul. Poznanska 2, 35-959 Rzeszow, Poland, e-mail: apekala@prz.edu.pl

2 PhD., Eng., Rzeszow University of Technology, Faculty of Civil, Environmental Engineering and Architecture, al. Powstancow Warszawy 6,35-959 Rzeszow, Poland, e-mail: kpiet@prz.edu.pl
} 
of the main environmental factors determining network failure are soil conditions at the site of contact between soil and water supply pipe.

Many research concern issues of soil parameters influence on underground metal infrastructure since fifties last century. Nowadays the use of modern measurement tools as X-ray spectrometer or electron microscope allows to regard this issue in more complex view. Numerous studies indicate the importance of clay mineral contents onto the deterioration of buried structure of infrastructure. Also importance of performed research in terms of extension the pipe life and implementation of non-conducting materials eg. gravel or sound around the pipe was the aim of study presented in [1]. In aforementioned work, it is indicated that failure occurrence intensity on particular pipes strongly depends on soil parameters, as moisture content in the soil, soil $\mathrm{pH}$ and resistivity or chloride and sulphate.

Soil, according to [2], means rocks occurring in the substrate or around the object of human activity (construction or mining), which interact or will interact in the future with the object, according to the project. The interaction of soil with the object means that it affects the object and is subjected to influence of object. In this meaning, soil is every solid rock or in a state of dispersion, e.g.: sand, clay, silt and others.

This definition is similar to the existing in Polish (PN 86/B-02480) and international ISO standards (PN-EN ISO 14688), where soil is defined as a part of the earth's crust which could interact with the building object, being its element or serving as material for making earth structures [3,4]. The solid phase, i.e. soil framework is also called soil. Soil as a factor of the environment which affects the materials causes damage of the environment. Corrosion of water network often results from the soil characteristics. The main causes of such phenomena are:

- chemical soil composition and phase of soil framework, in particular the presence of soluble chloride-sulfate in water, such as gypsum, halite, anhydrite and others,

- porosity of soil, which can cause stop or flow of water,

- chemical composition of pore water,

- electrical conductivity,

- size of the redox potential,

- microbial activity.

Corrosiveness is intensified in moist centres, such process can also be fostered by stray currents, micro-organisms and minerals. The main indicator of corrosion aggressiveness of earthen environment is the amount of electrical resistance of rocks, land and soils. It is assumed that if the resistance is smaller, the degree of corrosion aggressiveness of environment is greater, which is 
presented in the Table 1-2 [5]. At greater depths, some soils despite the low value of electrical resistance are not subjected to rapid corrosion due to poor diffusion of the oxygen [6]. However, in these conditions can occur biotic corrosion, intensified by the action of sulphate-reducing bacteria.

Table. 1 Corrosion aggressiveness of lands and soil

\begin{tabular}{|c|c|c|}
\hline Corrosion & Volume resistivity & $\begin{array}{c}\text { Estimated time (in years) of corrosion for pipeline with 12 inches } \\
\text { aggressiveness }\end{array}$ \\
Low & 100 & diameter and wall thickness of 8 to 9 mm \\
\hline Normal & $20-100$ & 25 \\
Increased & $10-20$ & $10-25$ \\
High & $5-10$ & $5-10$ \\
Very high & $0-5$ & $3-5$ \\
\hline
\end{tabular}

Table. 2 Examples of resistivity depending on the soil character

\begin{tabular}{|c|c|}
\hline Type of soil & Volume resistivity $\Omega \mathrm{m}$ \\
\hline Organic soil & $30-50$ \\
Agricultural land & $90-150$ \\
Clay soil & $20-200$ \\
Wet gravel & $100-500$ \\
Dry sandy soil & $500-2000$ \\
Stony soil & $100-3000$ \\
\hline
\end{tabular}

Another important issue is the chemical composition and soil phase. Soil formations with low resistance to weathering parameters are characterized by higher salinity and hence the increase of the corrosion aggressiveness. The presence in the soil such components as sulphates, chlorides or mineral compounds with the ability of hydrophilic, may enhance the degree of soil corrosivity.

\section{DATA AND METHOD}

\subsection{FAILURE PIPES DATA AND PRELIMINARY ANALYSIS CONCERNING FAILURE OF STEEL PIPE}

Water supply network in the distinguished city in the Subcarpathian province has more than 70 years and the construction of the main network was completed in the forties, during that time gray cast iron and steel were used and are the oldest materials used in the construction of water supply network. In the early seventies for the construction of the distribution network and water supply connections plastic materials were also used as PVC. In the nineties the construction from water supply systems began from pipes made of PE. Firstly mostly water supply connections were built 
from this material, now from PE distributional pipes and mains are built. At present the operation of pipe lifetime of the water supply system is as follows: to 10 years about $18 \%$, from 11 years to 20 years $-24 \%$, from 21 to 30 years about $22 \%$, from 31 to 50 years $-33 \%$ and above 50 years is $3 \%$. Material composition of water network constitutes: $35 \%$ of steel, $26 \%$ of PE, $22 \%$ of PVC, cast iron about $17 \%$. In order to eliminate failures on the old sections, water pipes are being modernized, which will also help to reduce water losses.

In the research samples were gathered from the place of failure occurrence on the water network as to find out the influence of soil properties onto the steel. Data was gathered in the form of protocol as to conduct precise identification of emerging damages.

Data on failures concerning the water network are divided into following groups [7]:

A general information (addresses, dates, etc.),

A technical data (types of water network and its fittings considering their functionality, construction, technology, etc.),

A data on failure (type of event, cause, etc.),

A data on the effects and consequences of failure (type, scope of damage, causes, etc.),

A additional information.

The example of pipe failure occurred as the result of corrosion was presented on the Figure 1.

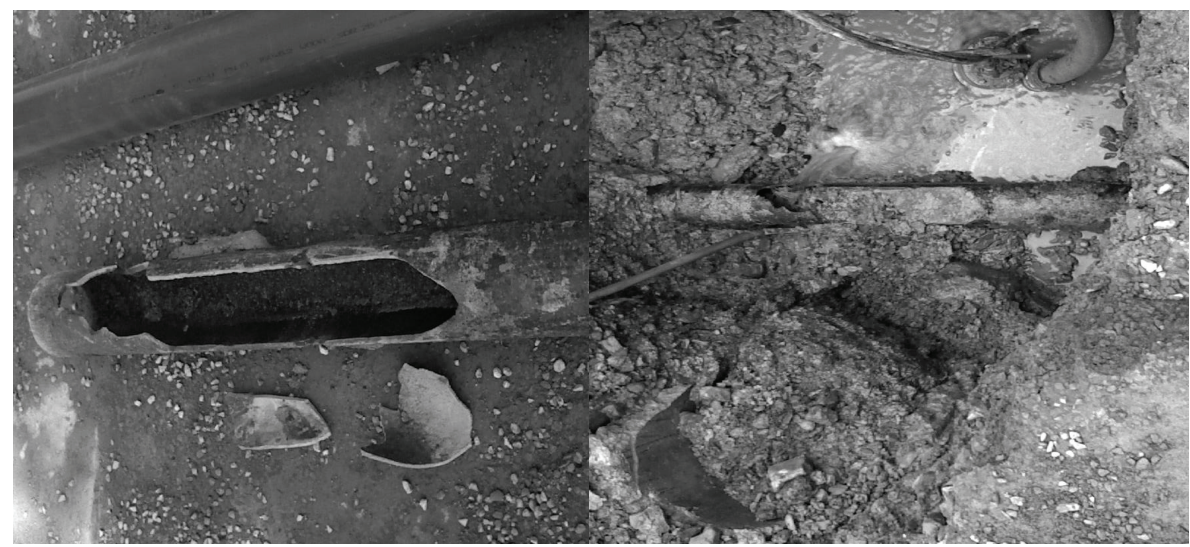

Fig. 1. The example of influence of soil properties to corrosion of water pipe (own study)

In order to present the real reference having regard to the length of the water pipes made of steel, number of failures occurring on this type of material was compared to the pipe length and presented 
as the failure rate $\lambda$. The important issue is also changeability and prediction of failure occurrence what is indicated in numerous research as in $[7,8]$. Results of our investigations are shown in Figure 2. Analyzing the values of the failure rates of the entire water network, it can be seen that these values tend to slightly increase and followed up in the high failure rate range of more than 0,5 of failures $/ \mathrm{km} /$ year according to criteria presented in $[9,10]$.

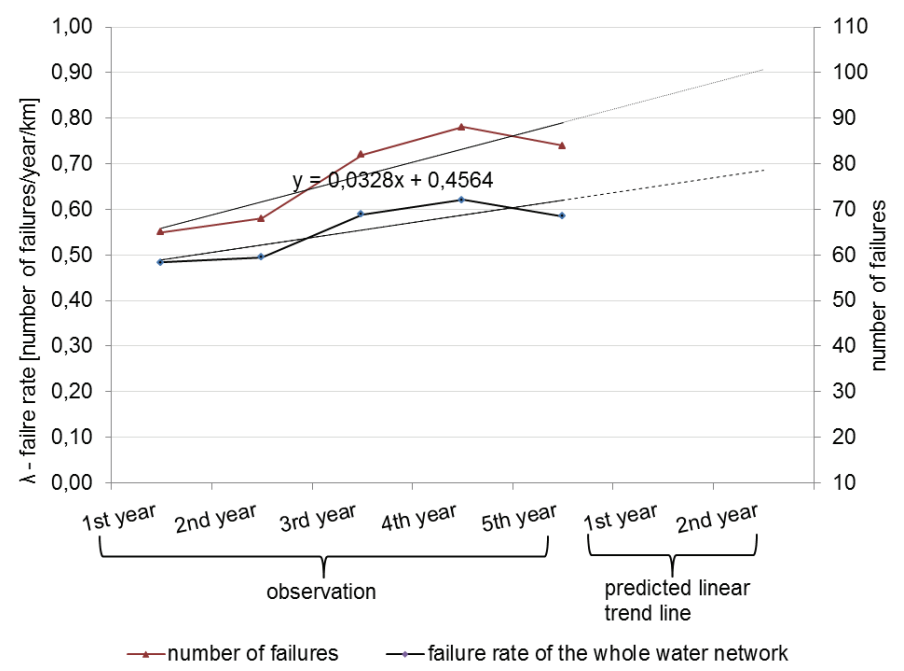

Fig. 2. Changeability of the failure rate and number of failures occurred on steel water pipe (own study)

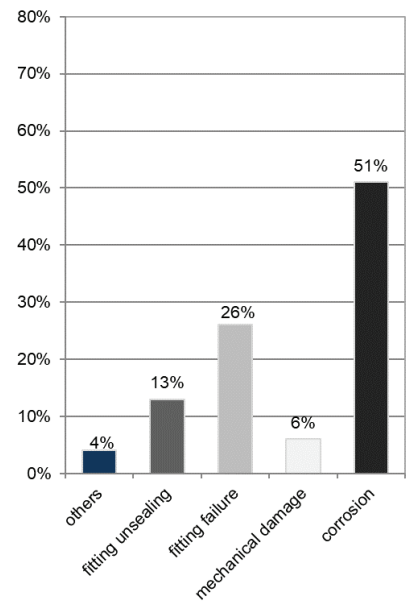

Fig. 3. The percentage distribution of failure reason of water network (own study) 
As can be seen many failures, because as $51 \%$ of all failures resulted from corrosion (Figure 3), which confirms the need to take into account the reduction of this kind of failure and detailed analysis of the causes and methods of preventing this kind of failure. Therefore, in the paper the analysis of soil conditions and its impact on the increased failure rate of water pipes is conducted.

\subsection{METHOD OF SOIL PROPERTIES RESEARCH}

Character of soil surrounding the pipe system damaged by the failure was defined on the base of mineralogical research. In order to determine the phase composition the following equipment was used: scanning electron microscope (SEM) FEI Quanta 200FEG, X-ray spectrometer (EDX Genesis), detector and backscattered electrons (BSE). The phase composition (qualitative and quantitative) was determined by implementing X-ray diffraction using the powder Debye-Sherrer's method. In the study X-ray diffractometer Philips PW X'PERT 3020 was used. In order to identify the type of mixed minerals from the separated fraction below $0.002 \mathrm{~mm}$, oriented slides were prepared, glycolated and calcined at $550^{\circ} \mathrm{C}$. Research for $\mathrm{pH}$ measurement was performed using a pH-meter CP-105 waterproof IP67 ELMATRON calibrated with buffer solutions of pH 4 and 7. The test was performed according to the standard ISO 10390:1997 [11].

\section{RESEARCH RESULTS AND DISCUSSION}

From the place of failure ten soil samples were collected. It was characterized by dark green color and directional texture. Geotechnical studies allowed to establish its initial physical characteristics. Factor accelerating corrosiveness material in the soil is the degree of its moisture. Dry land and soil are not cause corrosion, while wet can cause corrosion of metallic materials. Therefore, special attention in studies of geotechnical deserves parameter of natural humidity forming up in the tested material from 19,2 to $25,7 \%$ with an average value of $22,7 \%$, allowing them to classify it as wet soil. Macroscopically obtained material has similar characteristics, therefore as to perform accurately component identification mineralogical study was conducted on six selected samples of soil. The study allowed to characterize studied formation as clay soil. X-ray studies have shown that the basic components of the analysed soil are various clay minerals. In order to identify the exact nature of these minerals from the soil the samples of fractions $0,002 \mathrm{~mm}$ were isolated and oriented preparations were made, which were then glycolated and annealed at temperature of $550^{\circ} \mathrm{C}$. 
Analysis of separated clay fraction shows that it is represented by kaolinite, chlorite, illite and mixed package minerals in the Table 3. The ingredients of not clay soil revealed the presence of carbonate minerals, calcite and dolomite. Carbonates have also been confirmed in studies of soil using geotechnical methods according to standards (PN-ISO 10390:1997). Soil treated with 10\% hydrochloric acid solution foamed extensively $(++)$, what indicates about calcium carbonate content in the range from 3 to $5 \%$.

Table. 3. The mineral composition of the separated clay fraction

\begin{tabular}{|c|c|c|c|c|c|c|}
\hline No & No of sample & Sample name & Illite & Chlorite & Kaolinite & $\begin{array}{c}\text { Mixed package } \\
\text { minerals }\end{array}$ \\
\hline 1 & LJ $/ 1921$ & AP/G & + & + & + & + \\
\hline
\end{tabular}

Explanation: sign / + / indicates the presence of mineral phase in the sample soil

Phase silica was represented by quartz which appeared in the form of well-rounded grains. Quantitative analysis confirmed the presence in the studied rocks trace amounts of plagioclase and potassium feldspars. In the SEM image the attention was drawn to numerous granular framboidal pyrite (Figure.6a). This sulfide fills the empty spaces between the components of the clay. Also the crystalline forms of the mineral with isometric slice occur. Chemical analysis of the micro-area 1 and 3 (Figure $6 \mathrm{~b}$ ) confirm the presence of this component. The obtained results of the micro-area of chemical results draw attention to the total high Fe contents in relation to the other components Table 4.

4a)

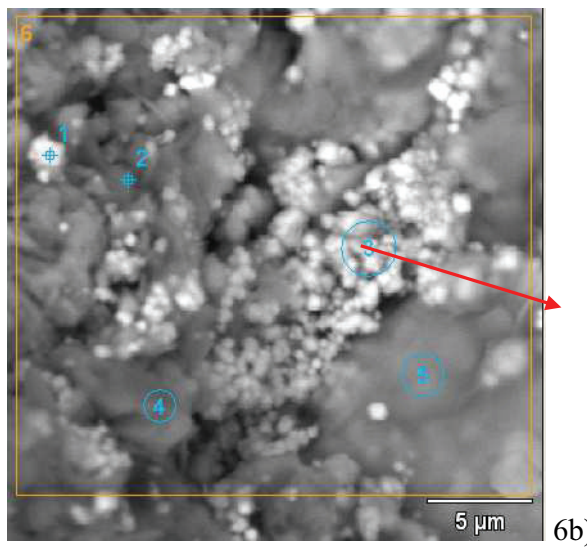

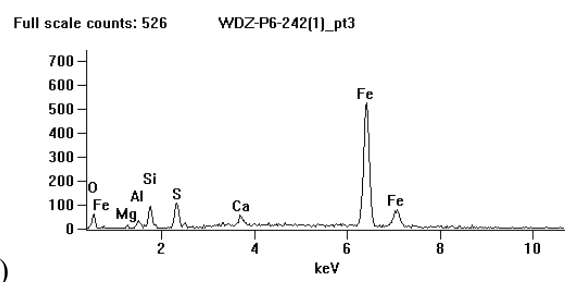


Fig. 4 a) Example SEM / EDX separable ground of the analysis. Explanation: 1 - pyrite; 2 - quartz; 3 - pyrite; 4.5 - clay minerals; 6 - micro-area analysis; b) The result of qualitative microanalysis of chemical composition in third section.

Table. 4. Results of quantitative microanalysis of the chemical composition in sixth area [Weight $\%$ ]

\begin{tabular}{lcccccccccc} 
& $\boldsymbol{O}-\boldsymbol{K}$ & $\boldsymbol{N a - K}$ & $\boldsymbol{M g}-\boldsymbol{K}$ & $\boldsymbol{A l - K}$ & $\boldsymbol{S i - K}$ & $\boldsymbol{S}-\boldsymbol{K}$ & $\boldsymbol{K}-\boldsymbol{K}$ & $\boldsymbol{C a}-\boldsymbol{K}$ & $\boldsymbol{M n}-\boldsymbol{K}$ & $\boldsymbol{F e}-\boldsymbol{K}$ \\
\hline $\boldsymbol{p t \boldsymbol { 1 }}$ & 16.80 & - & - & 1.10 & 3.62 & 29.66 & - & 2.05 & - & 46.77 \\
$\boldsymbol{p t 2}$ & 5.27 & - & 0.57 & 3.27 & 13.31 & 2.94 & 1.99 & 2.48 & 4.11 & 66.05 \\
$\boldsymbol{p t 3}$ & 3.12 & - & 0.23 & 0.84 & 2.23 & 3.50 & - & 1.87 & - & 88.22 \\
$\boldsymbol{p t 4}$ & 50.17 & 10.43 & - & 8.69 & 27.49 & 0.84 & - & - & - & 2.38 \\
$\boldsymbol{p t 5}$ & 31.90 & - & 4.66 & 7.01 & 11.40 & 9.11 & 1.87 & - & - & 34.04 \\
$\boldsymbol{p t 6}$ & 25.31 & 1.32 & 1.17 & 4.26 & 9.59 & 8.08 & 0.99 & 5.03 & - & 44.24 \\
\hline
\end{tabular}

The results of the exchange acidity of the soil, based on the $\mathrm{pH}$ measured in $\mathrm{KCl}$ at a concentration of $1 \mathrm{~mol} / \mathrm{dm}^{3}$ indicate to the acid character of the soil. The obtained results are in the range from 4,5 to 6,4 with an average value of 5,3. Only one of the tested samples obtained $\mathrm{pH}$ equals 6,4 typical for slightly acidic soil.

Soil as environment factor affect material, causing its corrosion. The corrosiveness of the environment is the natural result of many causes, which often makes it difficult to clear assessment of the causal factor. The exact specification of soil medium, based on specialized mineralogical research is helpful in determining the failure cause of engineering objects. Analysis of kind and degree of corrosively natural environment is of practical importance in making the right choice of metal material with regard to its destination and estimated time of operation. From the conducted characteristics of clay soil, it can be concluded that the conditions in failure place conducive to corrosivity occurrence. Volume resistivity for particular soil is in the range of 20-200 ohm m, allowing them to qualify it to soil of normal corrosivity. However, in the mineralogical research the presence of pyrite can accelerate the phenomenon of corrosivity. During the oxidation of iron compounds comes to form sulfuric acid, which enhances the corrosivity of the materials, eg. concrete or iron. In addition, present in the soil mixed-package minerals clay, will be intensified by humidity increase, the increase in the amount of porewater, thus conducive to corrosiveness. It is 
not without significance acidic soil, which in our case with $\mathrm{pH}$ range of 4,5-6,4, will promote the intensification of the aggressive nature of the ground environment.

\section{SUMMARY}

Detailed mineralogical studies allow to show the influence of present minerals components in the rock and soil centers on their physical, chemical or mechanical characteristics. The author in her earlier works, confirms the influence of the silica mineral phases on the physical, chemical parameters of transitional rocks [12]. The carried out analyses of soil center pay attention to the influence of pyrite on the corrosiveness of materials that were made of iron. Described characteristics of the soil are conducive to different kinds of failures of engineering objects. Since the soil has the influence on the technical properties of the pipe, therefore it is really important to use bedding material around the pipes, which not possess the corrosive parameters. Only after precise recognition of the ground it can be prevented and possibly counteract from such threats. Also pipeline materials should be chosen for being used in construction of water pipe network taking into account the soil conditions, as $\mathrm{pH}$ or its chemical composition. Such decision should be made by experienced engineers as in future reduce the effects of the corrosive properties of the soil. Used in work mineralogical research methods seem to be necessary for the proper assessment of the risks arising from the nature of the ground environment. In detailed monitoring of the soil environment, GIS and remote sensing techniques help to visualize the parameters of the soil in spatio-temporal distributions [13].

Investigations were carried out as part of research contract of Faculty of Civil, Environmental Engineering and Architecture 


\section{REFERENCES}

1. J. Bhattarai. 2013. "Study on the corrosive nature of soil towards the buried-structures." Scientifc World, 11, pp. 43-47.

2. W.C. Kowalski, W.C. 1988. Geologia inżynierska. Wyd. Geologiczne, Warszawa

3. PN 86/B-02480: Grunty budowlane. Określenia, symbole, podział i opis gruntów.

4. PN-EN ISO 14688:Badania geotechniczne. Oznaczenie i klasyfikacja gruntów.

5. Lisowski, M. 2004. Pomiary rezystywności i przenikalności elektrycznej dielektryków. Wyd. Politechnika Wrocławska, Wrocław.

6. V. Ondrejka Harbulakova, A. Estokova, M. Kovalcikova. 2017. "Correlation analysis between different types of corrosion of concrete containing sulfate resisting cement," Environments, 4, pp. 1-14.

7. M. Kwietniewski, M. Roman, H. Kłoss-Trębaczkiewicz. "Niezawodność wodociągów i kanalizacji." Reliability of water system and sewerage). Arkady, Warsaw, Poland. 1993. (In Polish).

8. B. Tchórzewska-Cieślak, K. Pietrucha-Urbanik, M. Urbanik, "Analysis of the gas network failure and failure prediction using the Monte Carlo simulation method." Maintenance and Reliability, 18, 254-259, 2016. DOI:10.17531/ein.2016.2.13.

9. M. Iwanek, B. Kowalska, D. Kowalski, M. Kwietniewski, K. Miszta-Kruk, P. Mikołajuk. 2015. "Wpływ różnych czynników na awaryjność sieci wodociągowej w układzie przestrzennym - studium przypadku", Effect of Various Factors on Water Supply Network Failure in Spatial System - a Case Study, Czasopismo Inżynierii Lądowej, Środowiska i Architektury, JCEEA, t. XXXII, z. 62 (1/15), ss. 167-183. DOI: $10.7862 / \mathrm{rb} .2015 .12$

10. J. Rak, K. Boryczko, “Assessment of water supply diversification using the Pielou index." Conference: 5th National Congress of Environmental Engineering V, Lublin, Poland, 2017, pp. 53-58.

11.PN-ISO 10390:1997. Jakość gleby. Oznaczenie pH, metoda potencjometryczna na oznaczenia pH w $\mathrm{H}_{2} \mathrm{O}$ i $\mathrm{KCl}$.

12.A. Pekala, The influence of siliceous mineral phases on the mechanical properties of transitional rocks in the Belchatow lignite deposit”. Archives of Civil Engineering. Vol. LXI ISSUE 4 2015, DOI: 10.1515/ace-20150035

13.E. Głowienka, K. Michałowska, A. Pekala, „Spatio-temporal analysis of soil properties for the eastern border of European Union". Advances and Trends in Engineering Sciences and Technologies II, CRC Press, Taylor \& Francis Group, 2017, pp. 407-412, DOI/book/10.1201/9781315393827 


\section{LIST OF FIGURES AND TABLES:}

Table.1 Corrosion aggressiveness of lands and soil

Tabela.1 Agresywność korozyjna gruntów i gleb

Table. 2 Examples of resistivity depending on the soil character

Tabela. 2. Przykłady rezystywności w zależności od charakteru ośrodka gruntowego

Table. 3. The mineral composition of the separated clay fraction

Tabela.3. Skład mineralny wyseparowanej frakcji ilastej.

Fig. 1. The example of influence of soil properties to corrosion of water pipe

Rys. 1. Przykład wpływu właściwości gruntu na korozyjność przewodu wodociągowego

Fig. 2. Changeability of the failure rate and number of failures occurred on steel water pipe

Rys. 2. Zmienność intensywności uszkodzeń oraz liczby awarii występujących na stalowych przewodach wodociągowych

Fig. 3. The percentage distribution of failure reason of water network

Rys. 3. Rozkład procentowy przyczyn awarii sieci wodociągowej

Fig. 4 a) Example SEM / EDX separable ground of the analysis. Explanation: 1 - pyrite; 2 - quartz; 3 - pyrite; 4.5 - clay minerals; 6 - micro-area analysis; b) The result of qualitative microanalysis of chemical composition in third section

Rys.4 Przykładowy obraz SEM/EDX ośrodka gruntowego objętego analizą. Objaśnienia: 1 - piryt, 2-kwarc, 3-piryt, 4,5- minerały ilaste, 6- mikroobszar analizy

Table. 4. Results of quantitative microanalysis of the chemical composition in sixth area [Weight \%]

Tabela. 4. Wyniki ilościowej mikroanalizy składu chemicznego w obszarze 6 [Weight \%] 


\section{WPLYW ŚRODOWISKA GRUNTOWEGO NA KOROZYJNOŚĆ ORAZ AWARYJNOŚĆ INFRASTRUKTURY PODZIEMNEJ - NA PRZYKLADZIE WYBRANEGO SYSTEMU WODOCIĄGOWEGO}

Slowa kluczowe: parametry i właściwości gruntu, warunki występowania korozyjności, system zaopatrzenia w wodę

\section{STRESZCZENIE:}

W pracy przedstawiono zagadnienia związane $\mathrm{z}$ badaniami mineralogicznymi gruntu oraz awaryjnością sieci wodociągowej w odniesieniu do warunków gruntowych. Przewody wodociągowe stanowią znaczną część majątku przedsiębiorstw wodociągowych, dlatego też analiza dotycząca wpływu warunków gruntowych na wystąpienie awarii na przewodach wodociągowych stanowi ważne znaczenie w prawidłowej ocenie funkcjonowania systemów zaopatrzenia w wodę (WSS). Analizę wykonano na podstawie danych eksploatacyjnych dotyczących awaryjności rozpatrywanej sieci wodociągowej uzyskanych z Miejskiego Przedsiębiorstwa Gospodarki Komunalnej.

Analiza rodzaju i stopnia korozyjności środowiska ziemnego ma praktyczne znaczenie w dokonaniu właściwego wyboru materiału przewodu z uwzględnieniem jego przeznaczenia oraz przewidywanym czasem eksploatacji.

Największy udział w występowaniu awarii miały korozje. Intensywność uszkodzeń wykazała tendencję rosnącą, a w ostatnim roku przeprowadzonej analizy dla stalowych przewodów wodociągowych wyniosła $0,58 \mathrm{uszk} \cdot \mathrm{km}^{-1} \cdot \mathrm{rok}^{-1}$, $\mathrm{co}$ klasyfikuje ją jako kategorię wysokiej awaryjności $\lambda \geq 0,5 \mathrm{uszk} \cdot \mathrm{km}^{-1} \cdot \mathrm{rok}^{-1}$.

Wysoka awaryjność potwierdza konieczność zmniejszenia awarii powstających na skutek korozji, dlatego też w pracy przedstawiono analizę warunków gruntowych i ich wpływ na zwiększoną awaryjność przewodów wodociągowych.

Do analizy wzięto pod uwagę następujące właściwości warunków gruntowych jak: skład chemiczny i fazowy gruntu, w oparciu o analizy przeprowadzone za pomocą następujących urządzeń, jak mikroskop elektronowy z detektorem promieniowania rentgenowskiego spektrometru oraz detektor elektronów wstecznie rozproszonych (BSE) stosując metodę proszkową - Debyea-Sherrera oraz dyfraktometr rentgenowski.

Badania mineralogiczne wykazały, że podstawowymi składnikami analizowanych gruntów są różnorodne minerały ilaste. Analiza wyseparowanej frakcji ilastej pozwala stwierdzić, że reprezentują je kaolinit, chloryt, illit oraz minerały mieszanopakietowe. Ze składników nieilastych stwierdzono obecność minerałów węglanowych, kalcytu oraz dolomitu. Faza krzemionkowa reprezentowana jest przez kwarc który występuje w formie ziarn dobrze obtoczonych. Wykonana analiza ilościowa potwierdza $\mathrm{w}$ badanych gruntach śladowe ilości plagioklazów oraz skaleni potasowych. W przeprowadzonych analizach na uwagę zwracają liczne skupienia pirytu framboidalnego. Siarczek ten wypełnia puste przestrzenie między składnikami ilastymi. Spotyka się także formy krystaliczne tego minerału o pokroju izometrycznym. Stwierdzona w badanym ośrodku gruntowym obecność pirytu może przyspieszać zjawisko korozyjności przewodów wodociągowych. Podczas utlenienia związków żelaza dochodzi do utworzeniem kwasu siarkowego, który intensyfikuje korozyjność materiałów, np. betonu czy żelaza. Ponadto obecne w gruncie minerały ilaste mieszanopakietowe będą potęgowały wzrost wilgotności, zwiększały ilość wody porowej oraz przyśpieszały negatywne efekt zjawiska korozyjności.

Dokładna specyfikacja ośrodka gruntowego, oparta na specjalistycznych badaniach mineralogicznych jest pomocna przy określeniu przyczyny awarii obiektów inżynieryjnych. Analiza potwierdziła występowanie warunków gruntowych uznanych za korozyjne. 